\title{
Morphology of Puccinia horiana, Causal Agent of Chrysanthemum White Rust, Sampled From Naturally Infected Plants
}

G. O'Keefe and D. D. Davis, United States Department of Agriculture-Animal and Plant Health Inspection Service Plant-Protection and Quarantine, and Department of Plant Pathology and Environmental Microbiology, The Pennsylvania State University, University Park 16802

\begin{abstract}
O'Keefe, G., and Davis, D. D. 2015. Morphology of Puccinia horiana, causal agent of chrysanthemum white rust, sampled from naturally infected plants. Plant Dis. 99:1738-1743.

Chrysanthemum white rust (CWR), caused by Puccinia horiana, is pathogenic on many Chrysanthemum spp. and close relatives, and infects commercially important florist chrysanthemum cultivars (Chrysanthemum $\times$ morifolium) throughout the world. Due to regulations, most research and observations with CWR are done in vitro with symptomatic plants. In contrast, research presented herein is based on microscopic examination of symptomatic and asymptomatic plants collected from natural outbreaks in the field. We observed scattered (not in a linear pattern) telial sori on infected chrysanthemum leaves, stems, and flowers that coalesced at high infection levels. Teliospores were mainly two-celled but

occasionally one- or three-celled. Promycelia arose from the apical teliospore cell, the basal cell, or both. The number of basidiospores on promycelia varied from one to four. Germ tubes, arising from $P$. horiana basidiospores, penetrated the host epidermis directly without appressoria. A mucilaginous exudate formed at the site of attachment and penetration of leaf and stem tissue, as well as on internal cell walls. P. horiana colonization was systemic, with intercellular mycelium and intracellular M-haustoria in both symptomatic and asymptomatic infected host tissue. Hyphal anastomosis was observed within infected plants, suggesting that asexual fusion between different $P$. horiana pathotypes or genotypes might occur.
\end{abstract}

Chrysanthemum white rust (CWR), caused by Puccinia horiana Henn., is an autoecious, microcyclic rust that is pathogenic on many Chrysanthemum spp. and close relatives within the family Asteraceae. CWR is economically important and infects florist chrysanthemum cultivars (Chrysanthemum $\times$ morifolium) throughout the world (Anonymous 2011; Baker 1967; Dickens 1990; Firman and Martin 1968; Horst and Nelson 1997). Due to its worldwide importance and economic significance, many countries, including the United States, have established Phytosanitary Quarantines (United States Code of Federal Regulations 2014) against CWR. Although CWR does not directly result in chrysanthemum death, growers with infected plants often experience severe economic loss due to federal regulations requiring eradication of chrysanthemum crops.

CWR is indigenous to Japan, where it was first reported in 1895 (Baker 1967; Hiratsuka 1957). By the 1960s, CWR was found throughout Europe and later spread to Africa, Oceania, South America, and additional countries in Asia. In North America, CWR has been reported in Mexico (EPPO/CABI 2004) as well as in New Jersey and Pennsylvania (in 1977), Oregon and Washington (in 1990), and California (in 1991) (O'Keefe and Davis 2012).

$P$. horiana morphology was described in general terms by several authors in the 1960s and early 1970s, including Firman and Martin (1968), Kapooria and Zadoks (1973), and Punithalingam (1968), as follows. $P$. horiana produces only two spore stages, dikaryotic or diploid teliospores and haploid basidiospores. Because pycnia, which produce spermatia, are not produced, the process by which karyogamy occurs in $P$. horiana is unknown. Although multiple nuclei have been reported within $P$. horiana mycelium (Kapooria and

\section{Corresponding author: D. D. Davis; E-mail: ddd2@psu.edu}

*The $\boldsymbol{e}$-Xtra logo stands for "electronic extra" and indicates that two supplementary figures are published online.

Accepted for publication 11 May 2015.

http://dx.doi.org/10.1094/PDIS-02-15-0239-RE

(c) 2015 The American Phytopathological Society
Zadoks 1973), anastomosis within infected chrysanthemum tissues has not been reported.

Kapooria and Zadoks (1973) illustrated the morphology and cytology of $P$. horiana promycelium and basidiospore formation using line drawings and one page of limited microscopic images. They reported that teliospores germinated from one or both cells but usually from the apical cell. Germinating teliospores formed long, slender promycelia on glass slides. In contrast, developing promycelia on infected leaves were short and thick. In either case, after $12 \mathrm{~h}$ of germination, two septa formed within each promycelium and up to four reniform to round basidiospores were produced from the two distal cells. The first basidiospore was usually produced at the distal part of the apical promycelium cell. Basidiospores were usually produced on sterigmata, which were short, coiled, or curved. However, promycelia occasionally branched and formed basidiospores without visible sterigmata. Furthermore, Kapooria and Zadoks (1973) reported that, under high humidity and in the presence of free moisture, $P$. horiana basidiospores germinated by producing (i) a sharply tapering germ tube of varying length; (ii) an appressorium-like vesicle that eventually developed an infection hypha; and (iii) a secondary basidiospore, although rarely observed, that germinated by budding.

With rust fungi in general, the germ tube penetrates the host either directly through the epidermis or indirectly through stomata. In either case, rust fungi often release low levels of cell-wall-degrading enzymes at the penetration site. Haustoria form soon after penetration, and may further enzymatically degrade host cell walls. During early stages of colonization, these simple, filamentous, intracellular haustoria are very similar to intercellular hyphae (Larous and Lösel 1993a,b). Cell-wall-degrading enzymes allow the haustoria to enter the cell through the cell wall, initiate direct contact with the cell membrane, and begin to withdraw nutrients. In later phases of colonization, rust mycelia of dikaryotic rusts generally colonize the host mesophyll or vascular system via intercellular mycelium and form the more classic intracellular, branched, lobed haustoria. Finally, in some hosts, rust colonization may spread systemically, progressing from leaves to stems and roots (Bonde et al. 2015; Larous and Lösel 1993a,b).

In the late 1960s, Firman and Martin (1968) described four general stages of the $P$. horiana infection process: (i) development of germ tube and infection peg, with no distinct difference between a germ tube and an appressorium; (ii) formation of small fungal vesicles 
inside the host epidermis; (iii), formation of elongated fungal vesicles inside the host epidermis; and (iv) formation of septate fungal vesicles with branching hyphae. Bonde et al. (2015) recently described $P$. horiana penetration, colonization, and survival in greater detail using scanning electron microscopy (SEM) and transmission electron microscopy. They concluded, as did O'Keefe and Davis (2012), that $P$. horiana infection in chrysanthemum plants could be systemic and that systemic infection may provide a means of survival through winters. Bonde et al. (2015) also described direct penetration through the leaf cuticle, as well as colonization of the mesophyll by both inter and intracellular mycelium, and suggested that the pathogen might move within the transpiration stream. As colonization progresses, $P$. horiana signs and CWR symptoms develop on infected chrysanthemum plants. Infected plants initially exhibit yellow chlorotic spots on the adaxial leaf surface, possibly where airborne $P$. horiana basidiospores were deposited, germinated, and initiated infection. Later, telial pustules form on various portions of the infected plant, including leaves, stems, and flowers. However, systemic colonization may proceed asymptomatically, without production of visible symptoms or signs.

The main objective of this study was to illustrate morphological details of $P$. horiana collected from natural infections in the field from both symptomatic and asymptomatic CWR-infected plants. A second objective was to further the understanding of the host-parasite interaction by using several types of microscopy to examine naturally infected plant material. A third objective was to determine whether hyphal anastomosis occurred and, if so, to illustrate the phenomenon.

\section{Materials and Methods}

Examination of teliospore and basidiospore morphology. During fall 2012, chrysanthemum plants ('Savona Red') on the campus of The Pennsylvania State University, University Park, were exhibiting putative signs and symptoms of natural CWR infections. During the last week of October 2012, leaf and stem samples were collected from both asymptomatic and symptomatic plants. Leaf samples were set aside for later analyses. Subsamples of stem sections were washed with tap water to remove debris, surface sterilized with $10 \%$ bleach, and divided into two additional subsamples. DNA was extracted using a Qiagen DNeasy Plant Mini Kit and molecular analysis was performed on one subsample per protocols for $P$. horiana sequencing and quantitative polymerase chain reaction (qPCR) (Alaei et al. 2009a,b; O'Keefe and Davis 2012). If determined positive for $P$. horiana by qPCR and sequencing, the remaining (adjacent) subsample was processed for morphological examination using a compound microscope and SEM. Putative $P$. horiana structures were examined using a Nikon SMZ 1500 dissecting microscope and a Nikon 80i compound microscope. Fresh samples of telia, promycelia, and intercellular P. horiana structures were free-hand sectioned and mounted in either $0.05 \%$ lactoglycerol cotton blue or $0.05 \%$ lactoglycerol. Sections were viewed at $\times 10, \times 40, \times 60$, and $\times 100$. Microscopic images were captured with a Nikon DS-Fil digital camera and edited for clarity, when necessary, with Helicon Focus 4.4 software (Helicon Soft Ltd.) as well as Adobe Photoshop (Adobe Systems). Morphology of $P$. horiana teliospore development, promycelium formation, and basidiospore formation and germination, as well as systemic infection and colonization, was described and photographed.

Collection of basidiospores. Prior to examination, basidiospores were collected in sterile distilled water drops on acid-washed glass slides. Collection was achieved by attaching CWR infected leaves that contained germinating telia to the underside of a petri plate cover. The cover was placed over the slide, which was resting in the bottom of a petri plate containing distilled water to maintain elevated humidity. Samples were incubated in the dark at $18^{\circ} \mathrm{C}$ until examination. Slides containing basidiospores were examined after 2, 4, 6,8 , and $24 \mathrm{~h}$ of incubation. Basidiospore dimensions were measured and occurrence of germination recorded.

Examination of teliospores and mycelia. Intact telia with teliospores attached to host leaves or stems were free-hand sectioned 2, $4,6,8$, and $24 \mathrm{~h}$ after collection. Telia and teliospores were removed from telial sori using a fine needle, mounted on glass slides, and examined. Thick mycelial mats on the plant surface were teased apart to reveal individual hyphal strands. DNA was extracted from mycelial mats and confirmed as $P$. horiana by PCR. Internal mycelia were observed within the mesophyll after stripping the leaf epidermis from the rest of the leaf. DNA was extracted and confirmed as P. horiana by PCR. Telia were examined mainly for telia and teliospore morphology, teliospore germination, promycelium development, and basidiospore formation. Mycelia were examined to describe hyphal morphology, as well as to document the presence of haustoria and anastomosis.

SEM. Subsamples from samples determined to be positive for P. horiana per PCR were prepared for SEM (Dykstra and Reuss 2003; Hall and Hawes 1991). Samples containing telial sori were freehand sectioned through sori prior to fixation. Samples consisting of asymptomatic stems were also sectioned prior to fixation. Specimens were fixed overnight at $4{ }^{\circ} \mathrm{C}$ in $2.8 \%$ (vol/vol) glutaraldehyde in 0.1 M HEPES buffer (pH 7.2) and $0.02 \%$ (vol/vol) Triton X-100 at room temperature for 2 to $4 \mathrm{~h}$. Samples were washed three times in buffer for 15 min each and fixed in $1 \% \mathrm{OsO}_{4}$ in $0.1 \mathrm{M}$ HEPES buffer (pH 7.2) with $0.02 \%$ Triton $\mathrm{X}-100$ in a dark container at $4{ }^{\circ} \mathrm{C}$ for $24 \mathrm{~h}$. Samples were washed three times in the same buffer for $15 \mathrm{~min}$ each prior to dehydration in a percent graded acetone series $(20,30,40,50$, $60,70,80,90$, and $3 \times 100 \%$ ) for 15 min each. Each sample was critical point dried in a Bal-Tec CPD030 dryer, mounted to an aluminum stub with conductive tabs sputter-coated with $10 \mathrm{~nm}$ gold palladium $(\mathrm{Au} / \mathrm{Pd})$, and examined under either a JSM5400 scanning electron microscope, a FEI Quanta 200 environmental scanning electron microscope, or a Zeiss Merlin compact scanning electron microscope.

Microtome thin sectioning. Symptomatic subsamples (only), taken from positive samples as determined per PCR, were prepared for thin sectioning. Stem sections were sectioned into 5-mm subsamples and fixed overnight at $4^{\circ} \mathrm{C}$ in $2.8 \%$ (vol/vol) glutaraldehyde in $0.1 \mathrm{M}$ HEPES buffer (pH 7.2) and $0.02 \%$ (vol/vol) Triton X-100 at room temperature for 2 to $4 \mathrm{~h}$. Subsamples were washed three times in buffer for $15 \mathrm{~min}$ each and fixed in $1 \% \mathrm{OsO}_{4}$ in 0.1 HEPES buffer (pH 7.2) with $0.02 \%$ Triton $\mathrm{X}-100$ in a dark container at $4^{\circ} \mathrm{C}$ for $24 \mathrm{~h}$. Subsamples were washed three times in the same buffer for $15 \mathrm{~min}$ each prior to dehydration in a percent graded acetone series $(20$, $30,40,50,60,70,80,90$, and $3 \times 100 \%$ ) for 15 min each. Each subsample was infiltrated with acetone and Spurr's resin at 3:1 for 2 to $4 \mathrm{~h}, 1: 1$ overnight, and $3: 1$ for 10 to $12 \mathrm{~h}$. Subsamples were infiltrated with $100 \%$ Spurr's resin overnight, then again for 10 to $12 \mathrm{~h}$ and overnight prior to embedding and polymerization in the resin at $60^{\circ} \mathrm{C}$ for 2 days. Embedded subsamples were thin-sectioned with a microtone, mounted on glass slides, and examined with an Olympus BX41 compound microscope. Images were captured with cellSens software (Olympus Corp of the Americas) and edited for clarification as needed.

\section{Results}

Specimens collected in the field at the site of a CWR outbreak allowed observation of $P$. horiana teliospore and basidiospore formation and germination collected from a natural setting. Importantly, colonization of stem and leaf tissue was observed in samples collected from both symptomatic and asymptomatic chrysanthemum plants via compound microscopy and SEM. Telia on symptomatic chrysanthemum leaves and stems were often aggregated in clusters approximately 1 to $5 \mathrm{~mm}$ in diameter. Telial clusters were compact, hard, and pink to dark pink in color. Individual teliospores were mainly two-celled but occasionally one- or three-celled, and were borne on persistent, hyaline pedicels arising from a basal layer of sporogenous cells. Teliospores were oblong or clavate, and were 28 to 43 by 8 to $18 \mu \mathrm{m}$. Teliospores were commonly observed within sori on the plant surface but were also observed within the stem beneath telial sori (Fig. 1A).

Promycelia usually arose from the apical telial cell but, at times, were produced from the basal cell (Fig. 1B) or from both cells (Supplementary Fig. S1B). The promycelium was long and tubular, 65 by $5 \mu \mathrm{m}$, and occasionally greater than $155 \mu \mathrm{m}$ in length. One or more septa were observed within the promycelium; when septa were 
present, basidiospores formed from the distal cell. Sterigmata were not always visible. P. horiana basidiospore formation as well as the attenuated conical shaped sterigmata are illustrated in Supplementary Figure S1C.

Basidiospores observed in telial clusters (Supplementary Fig. $\mathrm{S} 2 \mathrm{E}$ ) as well as on geminating promycelium and developing from teliospores (Supplementary Fig. S2A) were oval to kidney shaped, 13 by $6 \mu \mathrm{m}$, with a roughened wall. Upon germination on the leaf surface, the basidiospores produced a single germ tube that emerged from the spore (Fig. 1C; Supplementary Fig. S1D). Secondary basidiospores formed by budding were also observed.

A mucilaginous exudate formed at the site of attachment and hyphal penetration of the leaf epidermis and, later, around tissue being colonized by $P$. horiana. Neither appressoria nor stomatal penetration was observed. Germ tubes of various lengths developed from basidiospores and gave rise to hyphae. As colonization progressed, intercellular mycelium with intracellular M-haustoria and hyphae developed within both symptomatic and asymptomatic tissue, as observed using compound microscopy (Fig. 2B; Supplementary Figs. S1A and S2D) and SEM (Fig. 1D, E, and F). M-haustoria, a form associated with other basidiospore-induced rust infections, were observed using both compound microscopy and SEM. Mycelium was observed adhering to mesophyll cells (Supplementary Fig. S2B) in association with the xylem, and to contain septa (Fig. 1D and E).

Masses of vermiform branching hyphae with septa (Fig. 1E and F) and typical M-haustoria (Fig. 2B) (Larous and Lösel 1993a,b; Quilliam and Shattock 2003) were also observed within both symptomatic and asymptomatic host stem tissue. Infectious mycelia invaded the leaf spongy parenchyma mesophyll and formed telial primordia. Stalked teliospores erupted through the epidermis of both stem and leaf tissue (Fig. 3A, B, and C; Supplementary Fig. S2C and F). An apical cell of a $P$. horiana teliospore prior to germination is illustrated in Figure 2D. Colonizing mycelia occasionally followed vessel
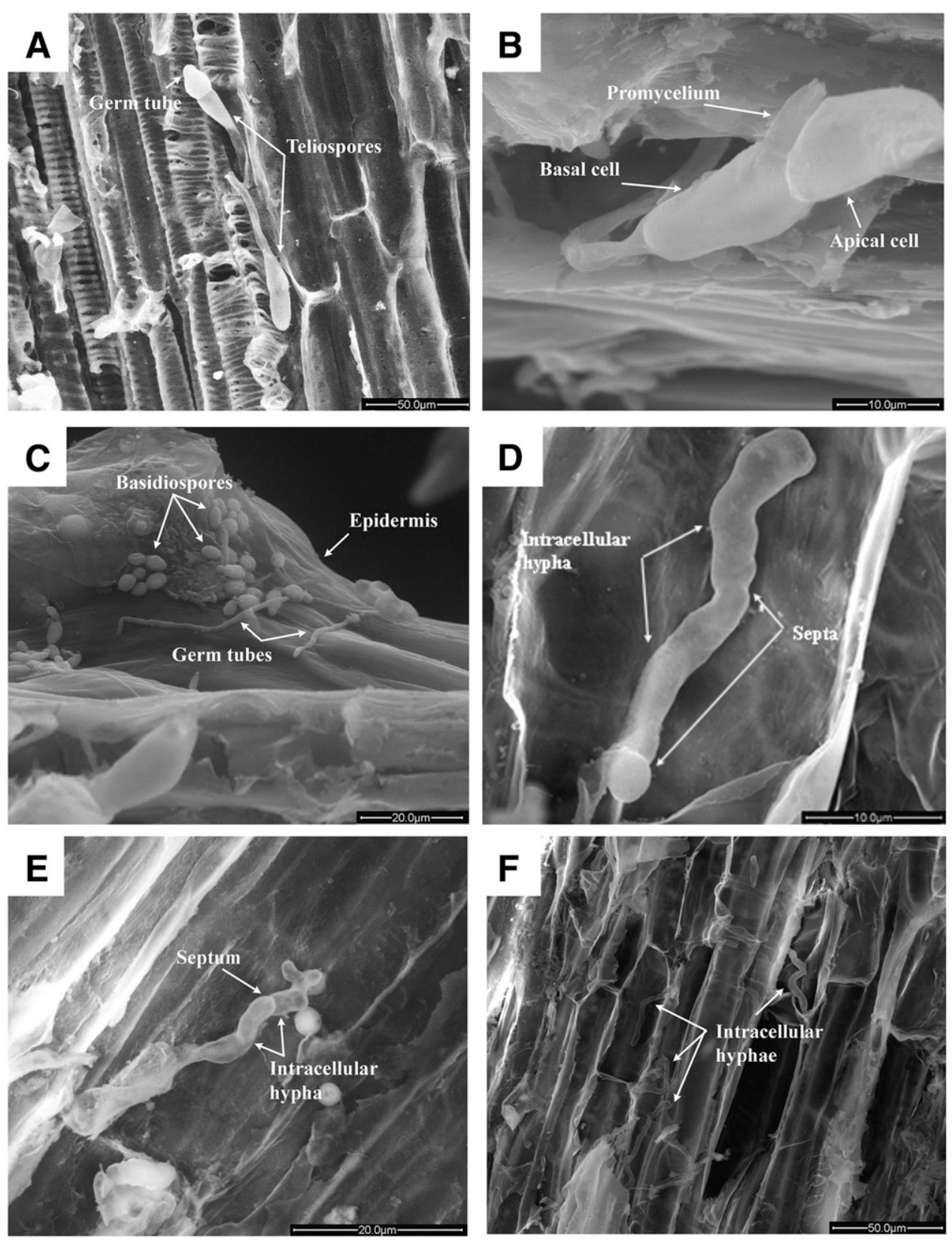

Fig. 1. Scanning electron microscopy images of Puccinia horiana taken with JSM5400 scanning electron microscope and a FEI Quanta 200 environmental scanning electron microscope. A, Teliospores within a symptomatic chrysanthemum stem. B, Teliospore with promycelium developing from the basal cell. C, Basidiospores and germ tubes on chrysanthemum leaf epidermis. D and $\mathbf{E}$, Intracellular hypha in a symptomatic chrysanthemum stem. F, Intracellular hypha within an asymptomatic chrysanthemum stem. 
elements in older infected specimens and anastomosis was observed between adjacent hyphal strands (Fig. 2A).

\section{Discussion}

The images produced by compound microscopy and SEM, as a result of this research performed in a natural setting, confirm that the morphologies of $P$. horiana teliospore sori, germinating teliospores, and germinating basidiospores were generally as described within earlier studies (Bonde 2015; Firman and Martin 1968; Kapooria and Zadoks 1973; Punithalingam 1968). However, this article provides additional detailed images of $P$. horiana colonization of symptomatic and asymptomatic chrysanthemum stems and leaves. Also, anastomosis between two strands of $P$. horiana hyphae is illustrated for the first time. We suggest that karyogamy results following anastomosis of compatible P. horiana hyphae. Occurrence of anastomosis suggests that this pathogen is able to reproduce parasexually, as discussed later.

Morphological details of $\boldsymbol{P}$. horiana. $P$. horiana telia formed on chrysanthemum leaves, stems, and flowers in an unorganized pattern that coalesced at high levels of infection. Although leaf telia were mostly hypophyllous, epiphyllous telia were also observed. Similar to other Puccinia spp., $P$. horiana telia originated subepidermally and then erupted through the host epidermis (Cummins and Hiratsuka 1984; Mendgen 1984). On the stems, teliospores were also observed associated within subepidermal tissues, presumably immediately beneath telial sori (Fig. 1A). Although this latter finding is unusual, we
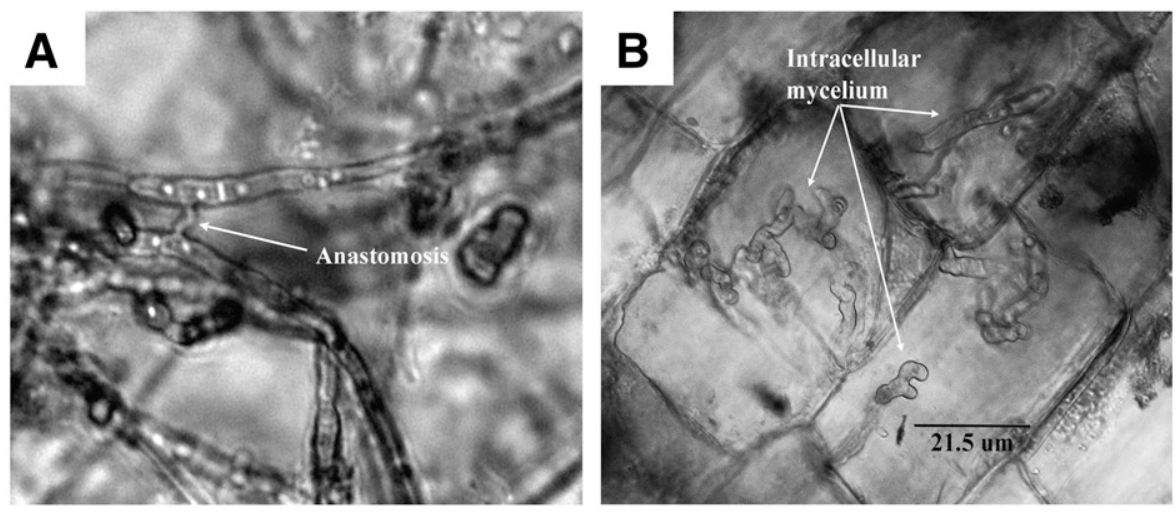

Fig. 2. Chrysanthemum white rust images of Puccinia horiana taken with Nikon $80 \mathrm{i}$ compound microscope. A, Anastomosis occurring between hyphal strands. B, Intracellular mycelia with M-haustoria in symptomatic chrysanthemum leaf tissue.
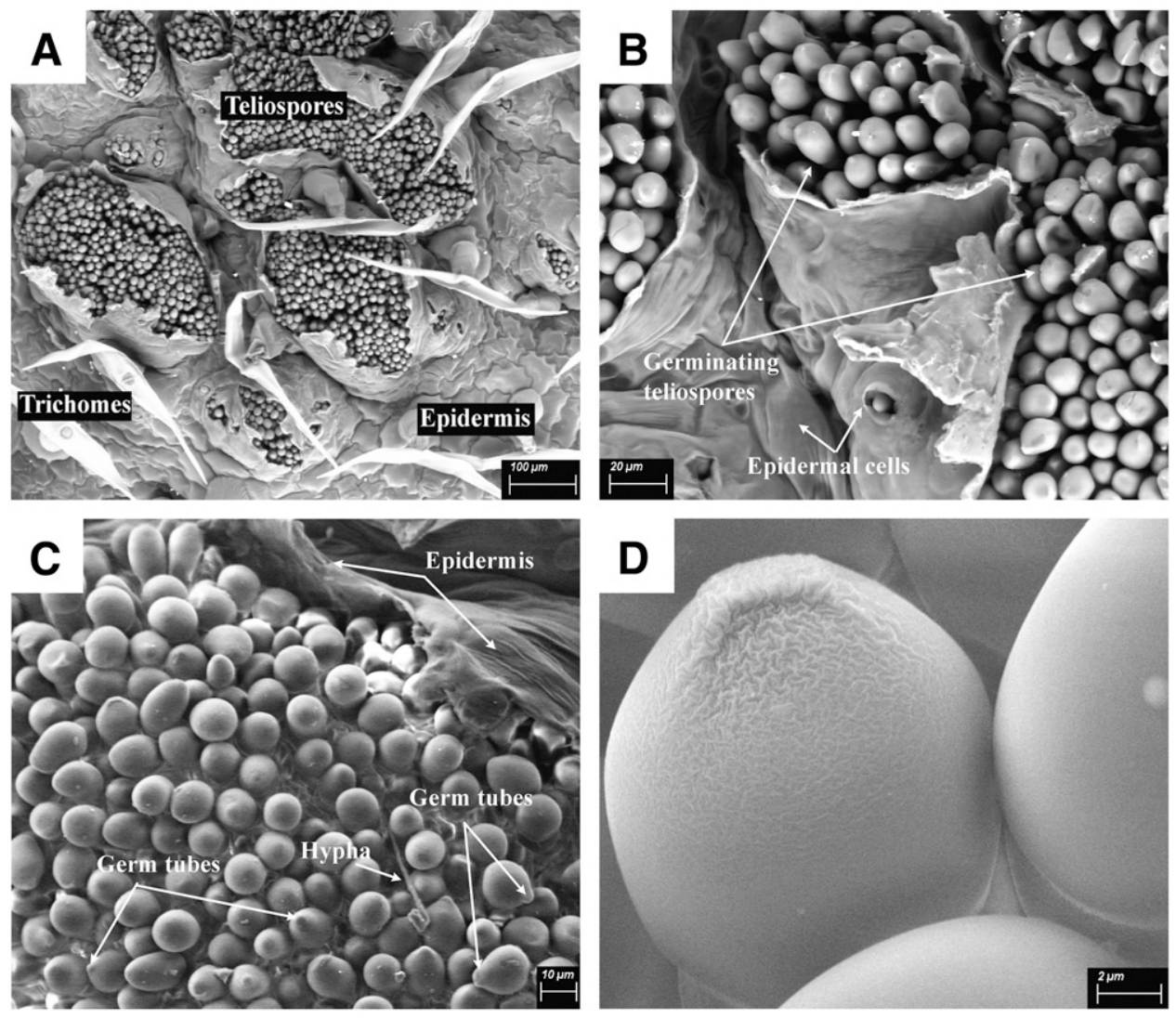

Fig. 3. Scanning electron microscopy images of Puccinia horiana taken with a Zeiss Merlin Compact scanning electron microscope. A and B, Teliospores erupting through chrysanthemum leaf epidermis. C, Germinating $P$. horiana teliospores erupting through symptomatic chrysanthemum leaf epidermis showing initial germ tubes emanating from teliospore tips. D, Apical cell of a $P$. horiana teliospore prior to germination. 
observed it in many images. However, it is unknown how the teliospores would function embedded within the vascular system or cortex, because teliospores must erupt through the host epidermis to disperse their basidiospores. Perhaps these images were of immature teliospores just prior to erupting through the stem surface. Additional research is needed to clarify this issue.

Punithalingam (1968) described P. horiana teliospores as being two-celled but we occasionally observed one- or three-celled teliospores. As reported by others (Firman and Martin, 1968; Kapooria and Zadoks, 1973), we observed that teliospores could germinate without a period of dormancy during spring, summer, or fall. Although not part of this study, we observed teliospores germinating within 14 days of inoculation in a dew chamber. Upon germination, promycelia typically formed from the apical telial cell, occasionally from basal cells, and, in some cases, from both cells, as previously illustrated in line drawings by Firman and Martin (1968) and Kapooria and Zadoks (1973). P. horiana promycelia were usually long and tubular, and often branched (Firman and Martin 1968; Kapooria and Zadoks 1973). We noted that the length and shape of promycelia within an infected plant was different from those on glass slides but not as dramatically different as that described in line drawings by Kapooria and Zadoks (1973). Sterigmata were not always visible but, when observed, had either attenuated tubes similar to those described by Kapooria and Zadoks (1973) or, more commonly, conical-shaped tips.

$P$. horiana basidiospore formation is illustrated in Supplementary Figure S1C. The number of basidiospores formed on each promycelium was difficult to ascertain but appeared to vary from one to four. De Backer (2012) and Kohno et al. (1974) reported that P. horiana normally produces two basidiospores per promycelium, whereas Kim et al. (2011) stated that the most common number was four. This discrepancy suggests that the number of $P$. horiana basidiospores per promycelium may vary with pathogen strain, host cultivar, or environmental factors. We also noted $P$. horiana basidiospore germ tubes that gave rise to hyphae or to secondary basidiospores formed by budding, as described by Kapooria and Zadoks (1973).

Colonization by $\boldsymbol{P}$. horiana. As described by Bonde et al. (2015), we observed that germ tubes arising from $P$. horiana basidiospores penetrated the host epidermis directly, without appressoria. We did not observe stomatal penetration and, in addition, noted that basidiospores germinated without noticeable germ tube swelling. Although many rust fungi produce appressoria on basidiospore germ tubes immediately prior to infection (Littlefield and Heath 1979), Waterhouse (1921) determined that appressoria were not required for host penetration in many rust fungi. Likewise, Larous and Lösel (1993a,b) and Plowright (1889) demonstrated that basidiospore germ tubes of some rust fungi were able to directly penetrate the host epidermis and initiate perennial mycelium in young stem tissue. Morin et al. (1992) also observed direct penetration of basidiospore germ tubes into host epidermal cells without appressorium formation. These latter references support our observations that appressoria are likely absent during $P$. horiana infections of chrysanthemum plants.

Colonization by $P$. horiana within systemically infected chrysanthemum plants was, at times, asymptomatic (Fig. 1F), and the outward appearance of colonized yet asymptomatic plants was similar to that of noninfected plants. This observation may help explain why CWR symptoms may suddenly appear years after a presumably healthy plant was obtained. In addition, symptoms such as swelling and elongation of shoots due to hypertrophy or hyperplasia are associated with monokaryotic phases of rust life cycles (Larous and Lösel 1993a,b). If there are any subtle growth alterations due to such monokaryotic infections of chrysanthemum by $P$. horiana, they might go unnoticed.

In general, biotrophic fungi often release cell-wall-degrading enzymes in sufficient quantities for localized weakening of defenses at the entry site of host cell walls (Larous and Lösel 1993a,b; Morin et al. 1992) Similar to observations of Bonde et al. (2015), we noted a mucilaginous exudate surrounding teliospores, as well as at the sites of attachment and penetration of both the leaf epidermis and internal cell walls. Gold and Mendgen (1984) determined that mucilaginous exudates anchor the penetrating mycelium to the host epidermis, seal the penetration site, protect the fungus from adverse conditions, and provide enzymes necessary for cell wall degradation. Bonde et al. (2013) also reported that $P$. horiana colonization among tracheid cells of chrysanthemum plants appeared to be aided by enzymes. Larous and Lösel $(1993 a, b)$ reported that cell-wall-degrading enzyme activity is necessary for mycelium to grow intercellularly within the host tissue. Similar to observations in other rusts (Larous and Lösel 1993a,b), we observed $P$. horiana colonizing mycelia following vascular tissue in older chrysanthemum host tissue.

$P$. horiana colonization in naturally infected chrysanthemum plants was systemic, with intercellular mycelium (Fig. 1D, E, and F) and intracellular haustoria (Fig. 2B), similar to that described by Bonde et al. (2013, 2015). We noted that some haustoria and many hyphae had septa, similar to other rust fungi (Chen et al. 1996). Littlefield and Heath (1979) presented the terms monokaryotic (M-Haustoria) for intracellular hyphae produced after basidiospore infection, and dikaryotic haustoria (D-haustoria) for true haustoria originating from aeciospore or urediniospore infections. We observed hyphae and M-haustoria (only) within both symptomatic and asymptomatic host tissue. The observation of $\mathrm{M}$-haustoria was expected, because $P$. horiana is a monokaryotic rust (Larous and Lösel 1993a,b; Quilliam and Shattock 2003). Presence of M-haustoria is also related to a microcyclic lifecycle, where telia develop after basidiospore germ tube infection, with or without pycnia being produced but without production of aeciospores or urediniospores (Quilliam and Shattock 2003).

Anastomosis in $P$. horiana. Anastomosis in $P$. horiana has not been previously been reported (De Backer 2012). This article provides the first observation that anastomosis (Fig. 2A) occurs within chrysanthemum plants infected with $P$. horiana. Although the sequence of events prior to and during anastomosis are poorly understood (Wang and McCallum 2009), documentation of anastomosis is important in plant-pathogenic fungi. Increased virulence in Puccinia spp. could occur via somatic hybridization through anastomosis, which is required in the parasexual cycle for many Puccinia spp. (Wang and McCallum 2009). This is the first cytological evidence demonstrating anastomosis in $P$. horiana and indicates that asexual fusion between different $P$. horiana pathotypes or genotypes can occur. Previously, it was believed that $P$. horiana reproduced only clonally. Our observations support those of De Backer (2012) and Ono (2002) that new, possibly more virulent pathotypes or genotypes may arise via anastomosis.

In summary, our research illustrates additional morphological details of the chrysanthemum- $P$. horiana pathosystem from the perspective of naturally infected symptomatic and asymptomatic plants. Our study expands the understanding of CWR from prior observations made on plants inoculated under controlled conditions. Our research also illustrates and confirms that hyphal anastomosis occurs in $P$. horiana.

\section{Acknowledgments}

This research was made possible by funding from The Pennsylvania State University, College of Agricultural Sciences, Department of Plant Pathology and Environmental Microbiology. We thank M. Hazen and J. Cantolina of the Microscopy and Cytometry Facility, Huck Institute of the Life Sciences, The Pennsylvania State University for their SEM technical expertise.

\section{Literature Cited}

Alaei, H., Baeyen, S., Maes, M., Höfte, M., and Heungens, K. 2009a. Molecular detection of Puccinia horiana in Chrysanthemum $\times$ morifolium through conventional and real-time PCR. J. Microbiol. Methods 76:136-145.

Alaei, H., De Backer, M., Nuytinck, J., Maes, M., Höfte, M., and Heungens, K. 2009b. Phylogenetic relationships of Puccinia horiana and other rust pathogens of Chrysanthemum $\times$ morifolium based on rDNA ITS sequence analysis. Mycol. Res. 113:668-683.

Anonymous. 2011. Chrysanthemum White Rust Bulletin. Syngenta Flowers Inc., Gilroy, CA.

Baker, J. J. 1967. Chrysanthemum white rust in England and Wales 1963-66. Plant Pathol. 16:162-166.

Bonde, M. R., Murphy, C. A., Bauchan, G. R., Luster, D. G., Palmer, C. L., Nester, S. E., and Berner, D. K. 2015. Evidence for systemic infection by Puccinia horiana, causal agent of chrysanthemum white rust, in chrysanthemum. Phytopathology 105:91-98

Bonde, M. R., Murphy, C. A., Bauchan, G. R., Luster, D. G., Palmer, C. L., Nester, S. E., Revell, J. M. and Berner, D. K. 2013. Systemic infection in chrysanthemum 
plants by Puccinia horiana, causal agent of chrysanthemum white rust. (Abstr.) Phytopathology 103:S2.18.

Chen, W.-Q., Gardner, D., and Webb, D. 1996. Biology and life cycle of Atelocauda koae, an unusual demicyclic rust. Mycoscience 37:91-98.

Cummins, G. B., and Hiratsuka, Y. 1984. Families of Uredinales. Rep. Tottori Mycol. Inst. Jpn. 22:191-208.

De Backer, M. 2012. Characterization and detection of Puccinia horiana on chrysanthemum for resistance breeding and sustainable control. Ph.D. dissertation, Ghent University. Faculty of Bioscience Engineering, Belgium.

Dickens, J. S. W. 1990. Studies on the chemical control of chrysanthemum white rust caused by Puccinia horiana. Plant Pathol. 39:434-442.

Dykstra, M. J., and Reuss, L. E. 2003:Pages 223-249, Chapter 9 in: Biological Electron Microscopy: Theory, Techniques, and Troubleshooting. Plenum Press, New York.

EPPO/CABI. 2004. Puccinia horiana. Quarantine Pests for Europe, 2nd ed. CAB International, Wallingford, UK.

Firman, I. D., and Martin, P. H. 1968. White rust of chrysanthemums. Ann. Appl. Biol. 62:429-442.

Gold, R. E., and Mendgen, K. 1984. Cytology of basidiospore germination, penetration, and early colonization of Phaseolus vulgaris by Uromyces appendiculatus var. appendiculatus. Can. J. Bot. 62:1989-2002.

Hall, J. L., and Hawes, C. 1991. Electron Microscopy of Plant cells. Academic Press, San Diego, CA.

Hiratsuka, N. 1957. Three species of chrysanthemum-rust in Japan and its neighboring districts. Sydowia Ser. 2 (Suppl. 1):34-44.

Horst, R. K., and Nelson, P. E. 1997. Compendium of Chrysanthemum Diseases. American Phytopathological Society Press, St. Paul, MN.

Kapooria, R. G., and Zadoks, J. C. 1973. Morphology and cytology of the promycelium and the basidiospore of Puccinia horiana. Eur. J. Plant Pathol. 79:236-242.

Kim, S., Nikolaeva, E., Olson, T., and Kang, S. 2011. Overwintering of chrysanthemum white rust caused by Puccinia horiana in Pennsylvania and challenges in its management. (Abstr.) Phytopathology 101:S91.

Kohno, M., Nishimura, T., Ishizaki, H., and Kunoh, H. 1974. Cytological studies on rust fungi, 1: Teliospore germination and nuclear behaviors in chrysanthemum white rust (Puccinia horiana P. Hennings). Bull. Fac. Agric. Mie Univ. (Jpn.) 47:1-9.
Larous, L., and Lösel, D. M. 1993a. Vascular infection by Puccinia menthae and other rust fungi. Mycol. Res. 97:409-414.

Larous, L., and Lösel, D. M. 1993b. Strategies of pathogenicity in monokaryotic and dikaryotic phases of rust fungi, with special reference to vascular infection. Mycol. Res. 97:415-420.

Littlefield, L. J., and Heath, M. C. 1979. Ultrastructure of Rust Fungi. Academic Press, NY.

Mendgen, K. 1984. Development and physiology of teliospores. Pages 375-398 in: The Cereal Rusts, Vol. I. W. R. Bushnell and A. P. Roelfs, eds. Academic Press, Orlando, FL.

Morin, L., Brown, J. F., and Auld, B. A. 1992. Teliospore germination, basidiospore formation and the infection process of Puccinia xanthii on Xanthium occidentale. Mycol. Res. 96:661-669.

O'Keefe, G., and Davis, D. D. 2012. First confirmed report that Puccinia horiana causal agent of chrysanthemum white rust, can overwinter in Pennsylvania. Plant Dis. 96:1381.

Ono, Y. 2002. The diversity of nuclear cycle in microcyclic rust fungi (Uredinales) and its ecological and evolutionary implications. Mycoscience 43:421-439.

Plowright, C. B. 1889. A monograph of the British Uredineae and Ustilagineae, with an account of their biology including the methods of observing the germination of their spores and of their experimental culture. Paul, Trench \& Co., London.

Punithalingam, E. 1968. Puccinia horiana. CMI Descriptions of Fungi and Bacteria 176:1-2.

Quilliam, R. S., and Shattock, R. C. 2003. Haustoria of microcyclic rust fungi Uromyces ficariae and Puccinia tumida and other gall-forming species, $U$. dactylidis (macrocyclic) and P. smyrnii (demicyclic). Plant Pathol. 52: 104-113.

United States Code of Federal Regulations. 2014. Plants for Planting. §Title 7. Part 319.37-2. USDA-APHIS-PPQ, Washington, D.C.

Wang, X., and McCallum, B. 2009. Fusion body formation, germ tube anastomosis, and nuclear migration during the germination of urediniospores of the wheat lea rust fungus, Puccinia triticina. Phytopathology 99:1355-1364.

Waterhouse, W. L. 1921. Studies in the physiology of parasitism. VII. Infection of Berberis vulgaris by sporidia of Puccinia graminis. Ann. Bot. (Lond.) 35: 557-564. 